\title{
Towards the Creative-Oriented University
}

\author{
MEHDI TAJPOUR ${ }^{2}$ \& ELAHE HOSSEINI*1
}

${ }^{1}$ Faculty of Economics, Management \& Accounting, Yazd University,

University Blvd, Safayieh, Yazd 8915818411, Iran.

${ }^{2}$ Faculty of Entrepreneurship, University of Tehran, $16^{\text {th }}$ Street, North Kargar Avenue, Tehran 1439813141, Iran.

\begin{abstract}
Entrepreneurial universities are the center of progressive organizations that have reconsidered themselves in order to adapt to complex environmental conditions. Thus, the purpose of this study is to investigate the towards the creative-oriented university. In this research, which has used descriptive methods, in order to understand the concepts of towards the creative-oriented university, the background of the subject has been studied in the form of library and documentary studies. Thus,conclusion show that the effect of entrepreneurial universities on a regional scale extends far beyond commercial outputs while a simple cost-benefit analysis can provide indirect and tangible results in terms of human capital attraction, entrepreneurial capital formation, informal networks, new ideas, and so on.
\end{abstract}

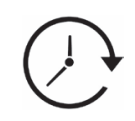

\author{
Article History \\ Received: 11 February \\ 2021 \\ Accepted: 14 April 2021
}

\author{
Keywords \\ Competition; \\ Innovation; \\ Entrepreneurship; \\ Entrepreneurial University.
}

\section{Introduction}

Entrepreneurship is a combination of social, political, economic and cultural elements in a region that supports the development and growth of investments based on creativity and innovation (Tajpour, Moradi, \& Jalali, 2018; Tajpour \& Salamzadeh, 2019). Entrepreneurship is also a phenomenon that occurs in different environments and settings. In addition, it leads to economic growth through innovations that people have created in response to economic opportunities (Chitsaz, Tajpour, Hosseini, Khorram, \& Zorrieh, 2019; Ziyae \& Tajpour, 2016).
In today's world, creativity and innovation are the engine of long-term competitiveness, which is an essential element in increasing and expanding production efficiency (2020). In addition, nowadays, creativity and innovation are considered to be the improving factor in the knowledge-based economy in such a way that the traditional thinking of the innovation process is changing and evolving (Philpott, Dooley, O'Reilly, \& Lupton, 2011). In terms of innovation, there is a relationship between university, industry and government that among these three factors, universities are more

CONTACT Dr. Elahe Hosseini 1 elahe.hosseini@stu.yazd.ac.ir 9 Faculty of Economics, Management \&Accounting, Yazd University, University Blvd, Safayieh, Yazd 8915818411, Iran.

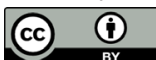

(c) 2021 The Author(s). Published by Enviro Research Publishers

This is an 2 Open Access article licensed under a Creative Commons license: Attribution 4.0 International (CC-BY).

Doi: http://dx.doi.org/10.12944/JBSFM.02.01.03 
Vol. 02(1\&2) 01-14 (2021)

important than the other two sectors due to providing new services (Tajpour,Hajian \& Nabaei,2017). Hence, the role of entrepreneurship is to stabilize economic growth by destroying sustainable and oldfashioned ways of doing business(Hosseini, Tajpour, \& Lashkarbooluki, 2020). Also due to various events that have taken place at the social, cultural and business levels in different countries, special attention is paid to entrepreneurship and entrepreneurs, and strengthening entrepreneurship in current organizations and creating a suitable platform for its development are two tools for economic development of countries, especially developing countries (Salamzadeh, Tajpour, \& Hosseini, 2020). Therefore, entrepreneurship includes all activities and actions related to understanding and exploiting opportunities (Tajpour, Hosseini, \& Salamzadeh, 2020). Therefore, entrepreneurial opportunities can be defined as a way to meet market needs through the creative combination of resources, which creates exceptional value (Nikraftar \& Hosseini, 2017). Entrepreneurship development in organizations can also pave the way for their success and prepare organizations for strategic changes (Tajpour \& Hosseini, 2020). Entrepreneurs are potentially available in any organization and efforts should be made to increase their capabilities, and most importantly, conditions should be provided for entrepreneurs in order to express themselves and realize their capabilities (Sabokro, Tajpour, \& Hosseini, 2018; Tajpour, Salamzadeh, \& Hosseini, 2019). Transparency and interaction between industry and university also show more excellentvalue for knowledge transfer between universities. In this way, challenges at the institutional level (promoting career advancement through new investments), organizational (stimulating economic growth through knowledge transfer) and individual (focusing on research and education are also discussed while engaging in entrepreneurial activities (Ziyae, Rezvani, Mobarki, \& Tajpour, 2019a). Therefore, cooperation between the three sectors of industry, government and university is necessary to promote the national system of creativity and innovation (Philpott et al., 2011). Therefore, if universities do not act like the entrepreneurial university and avoid involving in creating innovation, they will disrupt national and regional development and international competition (Tajpour, Moradi, \& Moradi, 2015). However, the environments that have been more dynamic than before have led universities to seek answers to this dynamism in order to achieve higher success and performance (Nikraftar \& Hosseini, 2016; Tajpour \& Hossini, 2014). Entrepreneurial university is involved as a trend in the development, evolution, and creativity of universities (Taucean, Strauti, \& Tion, 2018). So we can say that like catalyst the entrepreneurial university facilitates entrepreneurship that leads to the identification of opportunity and creativity in universities (Centobelli, Cerchione, \& Esposito, 2019; Khahande Karnama, Dehghan Najm Abadi, \& Tajpour, 2017). Therefore, the purpose of this study is to investigate the towards the creative-oriented university.

\section{Literature}

Universities are evaluated in ways that meet the social and economic needs of society. In developing countries, universities are almost the only institutions that can support the knowledge-based economy, and also the only institutions that can work in the field of new knowledge generation and technology transfer (Hosseini, Saeida Ardekani, \& Sabokro, 2020a). Therefore, entrepreneurial university plays a role as a trend in the development of universities (Taucean et al., 2018).However, for the successful development of the entrepreneurial university, the most critical mechanisms are the transformation of classical education and the necessary measures to create favorable internal and external conditions to ensure the strategic interaction in the government-universityindustry relationship that should be done in the best possible way. It varies from country to country but entrepreneurship is recognized as the most important field of education (Tayauova \& Bektas, 2018). Additionally, policymakers increasingly consider universities as the engine of economic growth through the commercialization of intellectual property through technology transfer (Tajpour, Demiryurek \& ilkay Abaci., In Press). The university's technology transfer business mechanisms include licensing agreements, joint research investments, and emerging corporateuniversity companies (Sharif \& Baark, 2008). The mission of the first-generation of universities has been education. In secondgeneration universities, the mission has been to research to meet the needs of society. Finally, the most important of them are third-generation universities in which they are expected to be 
Vol. 02(1\&2) 01-14 (2021)

entrepreneurial besides their mission of education and research (Henry, Foss, Fayolle, Walker, \& Duffy, 2015). Third-generation universities are generally entrepreneurial and based on entrepreneurship and they are expected to solve social problems with a scientific and systematic approach in interaction with the environment. In the third-generation university, the focus and mission of the university system is entrepreneurship (Mascarenhas, Marques, Galvão, \& Santos, 2017). The results of studies and research show that in third-generation university, entrepreneurship education and development of skills related to the goal of increasing creativity, improving motivation, desire for independence, taking advantage of environmental opportunities, initiative, risk-taking, commitment and enjoyment of uncertainty and complexity, is of vitalnecessity and requirement (Rubens, Spigarelli, Cavicchi, \& Rinaldi, 2017). Universities must face new challenges to meet the growing expectations of an entrepreneurial university whichis done through the interaction between education, research and entrepreneurship (Lahikainen, Kolhinen, Ruskovaara, \& Pihkala, 2019). Of course, it should be borne in mind that the entrepreneurship of universities does not conflict with the main programs and responsibilities of universities in teaching and developing educational-research services in society (Kanter, 1988).

Thus, the transformation from a traditionally-based research university to an entrepreneurial university is a common phenomenon, and the number of such transformations is increasing due to declining funding from government sources and the emergence of competitive markets in education (Tajpour \& Hosseini, 2019). It is evidentthat universities and higher education systems, in order to be more in line with the process of local, regional and international economic development move towards changing their traditional role which is only the production of knowledge, towards the entrepreneurial university which in addition to producing knowledge and creating ideas, they put them in practice (Tajpour \& Hosseini, 2019).

In addition, one of the most important methods in the development of entrepreneurial universities is the use of virtual social media for teaching and learning(Salamzadeh, Tajpour, \& Hosseini, 2019;
Tajpour et al., 2019). Accordingly, researchers consider entrepreneurial universities as a social system that seeks innovation and creativity in business activities (Tajpour, Hosseini, \& Moghaddm, 2018). Indeed, the entrepreneurial university is fundamental in creating fortifications and transferring scientific results to the market and, as a result, the implementation of such activities strengthens the social and economic development of the region (Tajpour, Moaddab, \& Hosseini, 2018; Ziyae, Rezvani, Mobarki, \& Tajpour, 2019b). Therefore, technology transfer, company formation, and regional development represent an towards the creativeoriented university (Ratten, 2017).

Organizational structure is another variable that affects the entrepreneurial activities of the university. The structure includes the size of the university, the structure of knowledge transfer (industry liaison offices, development centers, entrepreneurship centers, etc.) and the legal form of the university. Tangible factors are infrastructures such as business incubators and technology transfer offices, which are robustsupport mechanisms for knowledge commercialization activities such as startups, joint ventures, spin-offs and spin-offs. Intangible factors also include factors such as strategic focus, reward systems, entrepreneurial plans, reputation, and networks (Bronstein \& Reihlen, 2014). The entrepreneurial university thrives when its organizational structure comprises of almost a few layers (moving towards being organic) (Toshmali, Alimohammadzadeh, Maher, Hosseini,. , \& Bahadori, (2020). These structural features facilitate confrontation with innovative ideas at the lower levels of the organization and, consequently, they foster creative and unique management styles (Hosseini, Saeida Ardekani, \& Sabokro, 2020b; Nikraftar, Hosseini, \& Moghadam, 2017). Loss of focus on power and responsibility increases the likelihood of intermittent and effective communication by employees across the organization (Tajpour, Kawamorita, \& Demiryurek). (2020). It allows knowledge to be shared in ways that enhance innovation, risk-taking, and a desire for leadership and creative behavior (Penalva, 2021). In line with this trend, university regulations can boost entrepreneurship in some organizational and administrative parts of the university. Therefore, the 
existence of these regulations makes it possible to strengthen or limit entrepreneurship in the university (Fini, Grimaldi, \& Meoli, 2020).

Entrepreneurial cultures are also the critical factors in empowering academia and allow them to be creative and use their abilities (Saeeda Ardakani et al., 2020). When the concentration of power and responsibility is reduced, employees can make better decisions about the company's interests and they are also accountable for the outcome of their activities(Ireland, Kuratko, \& Morris, 2006). Managerial support shows the desire of managers to facilitate and promote entrepreneurial activities in the university (Salamzade et al., 2021). This support can come in many forms including: supporting innovative ideas, providing the necessary resources or expertise, and institutionalizing entrepreneurial activities in the organization's systems and processes (Hornsby, Kuratko, \& Zahra, 2002). University management must also recognize the diverse requirements of individuals about the implementation of high and low initiatives and empowerment in a particular subject. Proper understanding and implementation through advanced quality assurance processes should also be taken into account (Kirk, Newstead, Gann, \& Rounsaville, 2018). Consequently, identifying the components of institutions becoming entrepreneurial universities for internationalization should be studied and investigated (Taucean et al., 2018).

Resource-based theory claims that businesses can generate sustainable competitive advantage from their valuable, rare, unchangeable and irreplaceable resources (Li, 2015). Thus, it can be stated that paying attention to human resources, trying to attract financial resources, creating a decentralized structure and reducing bureaucracy are among the efforts that can lead the university towards entrepreneurship (Tajpour \& Hosseini, 2014).

In addition, universities are institutions that bring new entrepreneurial ideas and technologies to the forefront through the establishment of academic reproductive companies, which have been introduced as an critical element in the entrepreneurial ecosystem (Schillo, 2018). Indeed, the academic sector's propensity for entrepreneurship is influenced by the practical expectations of the emergence of fundamental innovations in knowledge (Ziyae \& Tajpour, 2016). As a result, public and private universities encourage the entrepreneurial process by creating advanced environments based on commercial incubators and technology parks (Dalmarco, Hulsink, \& Blois, 2018).

\section{Methodology}

The purpose of the present study is applied and the data collection method is qualitative. The research method is analytical and descriptive. The target population in this research is higher education institutions. In this study, in order to understand the concepts of the creative university, a library and documentary study was conducted. In other words, by referring to the research done and using library resources, the theoretical background of the entrepreneurial and creative university has been studied. While examining the relationship between government, university and industry, in order to explain the importance and impact of the university on the economy and also to explain the structures needed to achieve the standards of entrepreneurial and creative university, the existing records are checked out by searching the latest articles and related documents in the field of research. According to the main purpose of the research, it is necessary to move towards an entrepreneurial and creative university as a strategy for community development.

\section{Conclusion}

The entrepreneurial university represents universities that provide opportunities, practices, cultures and environments to encourage and accept the entrepreneurship of students and graduates. Therefore, this university plays a role in the development and transformation of higher education institutions, in which the components of entrepreneurship, mission, goals, and strategy to become an entrepreneurial university are discussed. So, entrepreneurship education in the university focuses primarily on the needs of the entrepreneur, while entrepreneurship education in the organization addresses a wide range of requirements of stakeholders, including: consumers and society. However, the key difference between the two terms is that the main focus of entrepreneurship education is on starting, growing and managing a business whereas the main focus of organizational training is on the acquisition and development of individual 
Vol. 02(1\&2) 01-14 (2021)

skills, abilities and characteristics that can be used in different fields and throughout life. Therefore it can be concluded that the towards the creativeoriented universityimpacts on the improvement of the economic and social situation of the community by changing the mentality and perception of people about innovation and creativity so as to build the process of business creation. Antowards a creativeoriented university is also a place where new jobs are created and this center supports entrepreneurs. This helping hand includes educational, financial and marketing support. Thus, these universities response to the growing importance of knowledge in the national system and areas of innovation and new perception of the university.

\section{Funding}

The author(s) received no financial support for the research, authorship, and/or publication of this article.

\section{Conflict of Interest}

The authors do not have any conflict of interest.

\section{Reference}

1. Saeida Ardekani S., Tajpour, M., \& Hosseini, E. (2020). The investigation of the Impact of Employee Empowerment on Knowledge Sharing in Post and Telecommunication Company (PTC) of Shiraz city. Management tomorrow, 18(60), 47-60.

2. Bronstein, J., \& Reihlen, M. (2014). Entrepreneurial university archetypes : A metasynthesis of case study literature. Industry and Higher education, 28(4), 245-262. https://doi. org/10.5367\%2Fihe.2014.0210

3. Centobelli, P., Cerchione, R., \& Esposito, E. (2019). Exploration and exploitation in the development of more entrepreneurial universities: A twisting learning path model of ambidexterity. Technological Forecasting and Social Change, 141, 172-194. https://doi. org/10.1016/j.techfore.2018.10.014

4. Chitsaz, E., Tajpour, M., Hosseini, E., Khorram, H., \& Zorrieh, S. (2019). The effect of human and social capital on entrepreneurial activities: Acase study of Iran and implications. Entrepreneurship and Sustainability Issues, 6(3), 1193-1203. http://doi.org/10.9770/jesi.2019.6.3(24)

5. Dalmarco, G., Hulsink, W., \& Blois, G. V. (2018). Creating entrepreneurial universities in an emerging economy: Evidence from Brazil. Technological Forecasting and Social Change, 135, 99-111. https://doi.org/10.1016/j. techfore.2018.04.015

6. Fini, R., Grimaldi, R., \& Meoli, A. (2020). The effectiveness ofuniversity regulations to foster science-based entrepreneurship. Research policy, 49(10), 104048. https://doi.org/10.1016/j. respol.2020.104048

7. Henry, C., Foss, L., Fayolle, A., Walker, E., \& Duffy, S. (2015). Entrepreneurial leadership and gender: Exploring theory and practice in global contexts. Journal of Small Business Management, 53(3), 581-586. https://doi. org/10.1111/jsbm.12174

8. Hornsby, J. S., Kuratko, D. F., \& Zahra, S. A. (2002). Middle managers' perception of the internal environment for corporate entrepreneurship: assessing a measurement scale. Journal of Business venturing, 17(3), 253-273. https://doi.org/10.1016/S08839026(00)00059-8

9. Hosseini, E., Saeida Ardekani, S., \& Sabokro, M. (2020a). Conceptual model of the voice of the members of the scientific board of public universities of Iran with the approach of interpretive structural modeling. Journal of Research on Management of Teaching in Marine Sciences.

10. Hosseini, E., Saeida Ardekani, S., \& Sabokro, M. (2020b). Presentation the Pattern of Knowledge Employees Voice (Case Study: Shiraz Gas Company Employees). Quarterly Journal of Public Organzations Managemen..8(4),57-72. http//doi/ 10.30473/ipom.2020.51818.4039

11. Hosseini, E., Tajpour, M., \& Lashkarbooluki, M. (2020). The impact of entrepreneurial skills on manager's job performance. International Journal of Human Capital in Urban Management, 5(4), 361-372. 
12. Ireland, R. D., Kuratko, D. F., \& Morris, M. H. (2006). A health audit for corporate entrepreneurship: innovation at all levels: part I. Journal of business strategy.27(1),10-17. https://doi.org/10.1108/02756660610640137

13. Kanter, R. M. (1988). When a thousand flowers bloom: Structural, collective, and social conditions for innovation in organizations. Knowledge Management and Organisational Design, 10, 93-131.

14. Khahande Karnama, A., Dehghan Najm Abadi, A., \& Tajpour, M. (2017). The relationship between entrepreneurial orientations and occupational performance at TUMS student health center. Journal of Payavard Salamat, 11(2), 124-133.

15. Kirk, S. H., Newstead, C., Gann, R., \& Rounsaville, C. (2018). Empowerment and ownership in effective internationalisation of the higher education curriculum. Higher Education, 76(6), 989-1005. https://doi.org/10.1007/ s10734-018-0246-1

16. Lahikainen, K., Kolhinen, J., Ruskovaara, E., \& Pihkala, T. (2019). Challenges to the development of an entrepreneurial university ecosystem: The case of a Finnish university campus. Industry and Higher education, 33(2), 96-107. https://doi. org/10.1177\%2F0950422218815806

17. Li, N. (2015). The internationalisation of Chinese transnational entrepreneurial firms: a comparative study with indigenous counterparts in Canada and UK. University of Glasgow, http:// theses.gla.ac.uk/id/eprint/6083

18. Mascarenhas, C., Marques, C. S., Galvão, A. R., \& Santos, G. (2017). Entrepreneurial university: towards a better understanding of past trends and future directions. Journal of Enterprising Communities: People and Places in the Global Economy. 11(3),316-338.https:// doi.org/10.1108/JEC-02-2017-0019

19. Nikraftar, T., \& Hosseini, E. (2016). Factors affecting entrepreneurial opportunities recognition in tourism small andmedium sized enterprises. Tourism Review. 71(1),6-17.https:// doi.org/10.1108/TR-09-2015-0042

20. Nikraftar, T., \& Hosseini, E. (2017). The effect of prior knowledge on entrepreneurial opportunity recognition (the Case study of tourism agencies participating in tourism fairs in Shiraz). Journal of Entrepreneurship Development, 9(4), 731748.https://dx.doi.org/10.22059/jed.2017.61551

21. Nikraftar, T., Hosseini, E., \& Moghadam, A. (2017). Identify factors affecting medical tourism attraction in Iran. Journal of Health Administration, 20(67), 64-74. http://jha.iums. ac.ir/article-1-2138-en.html

22. Penalva, J. (2021). Innovation and Leadership as Design: a Methodology to Lead and Exceed an Ecological Approach in Higher Education. Journal of the Knowledge Economy, 1-17. https://doi.org/10.1007/s13132-021-00764-3

23. Philpott, K., Dooley, L., O'Reilly, C., \& Lupton, G. (2011). The entrepreneurial university: Examining the underlying academic tensions. Technovation, 31(4), 161-170. https://doi. org/10.1016/j.technovation.2010.12.003

24. Ratten, V. (2017). Entrepreneurial universities: the role of communities, people and places. Journal of Enterprising Communities: People and Places in the Global Economy.11(3),310-315. https://doi.org/10.1108/JEC-03-2017-0021

25. Rubens, A., Spigarelli, F., Cavicchi, A., \& Rinaldi, C. (2017). Universities' third mission and the entrepreneurial university and the challenges they bring to higher education institutions. Journal of Enterprising Communities: People and Places in the Global Economy. 11(3),354372.https://doi.org/10.1108/JEC-01-2017-0006

26. Sabokro, M., Tajpour, M., \& Hosseini, E. (2018). Investigating the knowledge management effect on managers' skills improvement. International Journal of Human Capital in Urban Management, 3, .(2),125-132.http// doi/10.22034/ijhcum.2018.02.05

27. Salamzadeh, A., Tajpour, M., \& Hosseini, E. (2019). Corporate entrepreneurship in University of Tehran: does human resources management matter? International Journal of KnowledgeBased Development, 10(3), 276-292. https:// doi.org/10.1504/IJKBD.2019.103218

28. Salamzadeh, A., Tajpour, M., \& Hosseini, E. (2020). Exploring the Impact of Social Networks on Entrepreneurial Intention. Media Studies, 15(48), 111-124.

29. Salamzadeh,A., Tajpour,M., Hosseini, E., \& Salembrahmi,M.,(2021). Human Capital and the Performance of Iranian Digital Startups: The Moderating Role of Knowledge Sharing 
Behaviour, International Journal of Public Sector Performance Management.

30. Schillo, R. S. (2018). based spin-offs as agents in the entrepreneurial ecosystem. The Journal of Technology Transfer,43(1),222-239.https:// doi.org/10.1007/s10961-016-9484-5

31. Sharif, N., \& Baark, E. (2008). Mobilizing technology transfer from university to industry: The experience of Hong Kong universities. Journal of Technology Management in China.

32. Tajpour,M., Demiryurek,K \& ilkay Abaci,N.,(In Press). Design the Pattern of Increasing Satisfaction for International Students: A Qualitative Study with the Grounded Theory Approach, International Journal of Management in Education.

33. Tajpour, M., Hajian,F., \& Nabaei,A.M. (2017). The Impact of Suggestions to Entrepreneurial Opportunity Recognition Case Study: Bank Tejart of Iran, International Journal of Management Sciences and Business Research, 12, 45-53.

34. Tajpour, M., \& Hosseini, E. (2020). The Effect of Intelligence and Organizational Culture on Corporate Entrepreneurship in Shiraz Gas Compa. Human Resource Management in The Oil Industry, 12(45), 335-354. http://iieshrm.ir/ article-1-927-en.html

35. Tajpour, M., Hosseini, E., \& Moghaddm, A. (2018). The Effect of Managers Strategic Thinking on Opportunity Exploitation. Scholedge Int. J. Multi. Allied Stud, 5(2), 68-81. http://dx.doi. org/10.19085/journal.sijmas050602

36. Tajpour, M., Hosseini, E., \& Salamzadeh, $A(2020)$. The effect of innovation components on organisational performance: case of the governorate of Golestan Province. International Journal of Public Sector Performance Management, 6(6), 817-830. https://doi. org/10.1504/IJPSPM.2020.110987

37. Tajpour, M., \& Hossini, S. (2014). A Study of factors affecting Academic Entrepreneurship in University of Tehran Science and Technology Park. International Journal of Case, 3(10).

38. Tajpour, M., Moaddab, S., \& Hosseini, E. (2018). Entrepreneurship education and learning environment in institutions. Paper presented at the Proceeding of ICE2018. International Conference on Entrepreneurship. Tehran.

39. Tajpour, M., Moradi, F., \& Jalali, S. (2018).
Studying the influence of emotional intelligence on the organizational innovation. International Journal of Human Capital Urban Management, 3(1), 45-52. http//doi/ 10.22034/ ijhcum.2018.03.01.005

40. Tajpour, M., Moradi, F., \& Moradi, N. (2015). Identify the impact of emotional intelligence on corporate entrepreneurship. International Journal of Management, IT and Engineering, 5(11), 66-75.

41. Tajpour, M., \& Salamzadeh, A. (2019). The effect of spiritual intelligence on organisational entrepreneurship: case study of educational departments in University of Tehran. International Journal of Management and Enterprise Development, 18(3), 205-218. https:// doi.org/10.1504/IJMED.2019.100673

42. Tajpour, M., Salamzadeh, A., \& Hosseini, E. Job Satisfaction in IT Department of Mellat Bank: Does Employer Brand Matter?

43. Tajpour, M., Salamzadeh, A., \& Hosseini, E. (2019). Social Media and Entrepreneurship in Creative Industries. Paper presented at the Proceedings of the $2^{\text {nd }}$ International Conference of Research in Innovation and Technology, Tehran: Iran(2019) https://ssrn. com/abstract $=3625085$.

44. Tajpour, M. Hosseini ,E., (2019). Designing a pattern of University Social Responsibility in Higher Education Development with Emphasis on Corporate Entrepreneurship. Paper presented at the Conference: Ethics-oriented University ConferenceAt: Tehran, University of Tehran, Tehran.

45. Tajpour, M., Kawamorita, H., \& Demiryurek, K. (2020). Towards the third generation of universities with an entrepreneurial approach. International Journal of Technoentrepreneurship, 4(2), 122-133.https://doi.org/10.1504/ IJTE.2020.113927Taucean, I. M., Strauti, A. G., \& Tion, M. (2018). Roadmap to entrepreneurial university-Case study. Procedia-Social and Behavioral Sciences, 23(8),582-589. https://doi. org/10.1016/j.sbspro.2018.04.038

46. Tayauova, G., \& Bektas, C. (2018). An Overview of Entrepreneurial Universities and Main Barriers to Entrepreneurial University Development in Kazakhstan. The Journal of Economic Research \& Business Administration, , 124(2), 245-253. 
47. Toshmali, G., Alimohammadzadeh, K., Maher, A., Hosseini, S. M., \& Bahadori, M. Conceptualization of Entrepreneurial University and Pattern Design of Third Generation University.

48. Toshmali, G., Alimohammadzadeh, K., Maher, A., Hosseini, S. M., \& Bahadori, M.(2020). Conceptualization of Entrepreneurial University and Pattern Design of Third Generation University.

49. Ziyae, B., Rezvani, M., Mobarki, M. H.,
\&Tajpour, M. (2019b). Internationalization pattern of University with an Entrepreneurial Approach (case study: Iranian Universities). 12(2),301-320.https://dx.doi.org/10.22059/ jed.2019.285814.653079

50. Ziyae, B., \& Tajpour, M. (2016). Designing a comprehensive model of entrepreneurial university in the science and technology parks. World Journal of Entrepreneurship, Management and Sustainable Development. 12(3),267-280. https://doi.org/10.1108/WJEMSD-04-2016-0022 